\title{
Serious Fungal Infections in Ecuador
}

DOI:

10.1007/s10096-017-2928-5

\section{Document Version}

Accepted author manuscript

Link to publication record in Manchester Research Explorer

\section{Citation for published version (APA):}

Zurita, J., Denning, D., Paz-y-Miño, A., Solís, M. B., \& Arias, L. M. (2017). Serious Fungal Infections in Ecuador. European Journal of Clinical Microbiology and Infectious Diseases, 36(6), 975-981.

https://doi.org/10.1007/s10096-017-2928-5

\section{Published in:}

European Journal of Clinical Microbiology and Infectious Diseases

\section{Citing this paper}

Please note that where the full-text provided on Manchester Research Explorer is the Author Accepted Manuscript or Proof version this may differ from the final Published version. If citing, it is advised that you check and use the publisher's definitive version.

\section{General rights}

Copyright and moral rights for the publications made accessible in the Research Explorer are retained by the authors and/or other copyright owners and it is a condition of accessing publications that users recognise and abide by the legal requirements associated with these rights.

\section{Takedown policy}

If you believe that this document breaches copyright please refer to the University of Manchester's Takedown Procedures [http://man.ac.uk/04Y6Bo] or contact uml.scholarlycommunications@manchester.ac.uk providing relevant details, so we can investigate your claim.

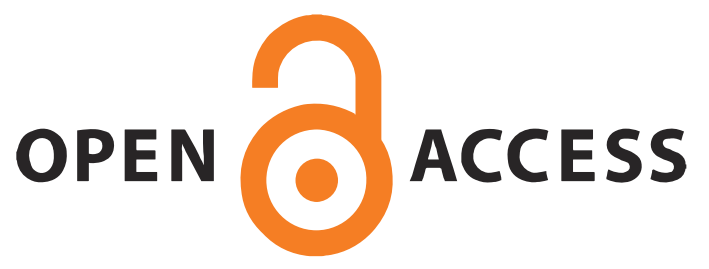




\section{Serious Fungal Infections in Ecuador}

Jeannete Zurita, ${ }^{1,3}$ David W. Denning, ${ }^{2}$ Ariane Paz-y-Miño, ${ }^{3}$ María Belén Solís, ${ }^{3}$ Luis Martin Arias. ${ }^{1}$

${ }^{1}$ Facultad de Medicina. Pontificia Universidad Católica del Ecuador. Quito Ecuador ${ }^{2}$ National Aspergillosis Centre, University Hospital of South Manchester and University of Manchester, Manchester UK United Kingdom

${ }^{3}$ Unidad de Investigaciones en Biomedicina. Zurita\&Zurita Laboratorios.

Corresponding author

Jeannete Zurita

jzurita@zuritalaboratorios.com

Key words: Fungal infections, epidemiology, mycology, Aspergillus, Pneumocystis.

Running head: Serious fungal infections in Ecuador 


\begin{abstract}
There is a dearth of data from Ecuador on the burden of life threatening fungal disease entities; therefore we estimated the burden of serious fungal infections in Ecuador based on the populations at risk and available epidemiological databases and publication. A full literature search was done to identify all epidemiology papers reporting fungal infection rates. WHO, ONU-AIDS, Index Mundi, Global Asthma Report and Globocan and National Data (Instituto Nacional de Estadística y Censos (INEC), Ministerio de Salud Pública (MSP), Sociedad de Lucha Contra el Cáncer (SOLCA), Instituto Nacional de Donación y Trasplante de Órganos, Tejidos y Células (INDOT)), were reviewed. When no data existed, risk populations were used to estimate frequencies of fungal infections, using previously described methodology by LIFE.

Ecuador has a variety of climates from the cold of the Andes through temperate to humid hot weather at the coast and in the Amazon basin. Ecuador has a population of $15,223,680$ people and an average life expectancy of 75 years. The median estimate of the HIV/AIDS population at risk for fungal disease ( $<200 \mathrm{CD} 4$ cell counts) is $\sim 10,000$, with a rate of $11.1 \%(1,100)$ of histoplasma, $7 \%$ (700) of cryptococcal meningitis and $11 \%$ (1,070) of Pneumocystis pneumonia. The burden of candidaemia is 1,037. Recurrent Candida vaginitis ( $\geq 4$ episodes per year) affects 307,593 women aged 15-50 years. Chronic pulmonary aspergillosis probably affects $\sim 476$ patients following TB. Invasive aspergillosis is estimated to affect 748 patients $(\sim 5.5 / 100,000)$. In addition, ABPA in asthma and SAFS were estimated to affect 26,642 and 45,013 people respectively. Our estimates indicate that $433,856(3 \%)$ of the population in Ecuador is affected by serious fungal infection
\end{abstract}




\section{Introduction}

Ecuador is located in the middle of the world on South America's west coast crossed by the Andean highlands and has a variety of climates from the cold of high mountains through temperate to humid hot weather in the coast, Galápagos Islands and Amazon jungle. According to the latest population census, Ecuador has a population of $14,483,495$ people and an average life expectancy of 76 years [2]. As fungal diseases are not reportable, exact data are not available and the current number of fungal infections occurring each year in Ecuador is not known. There is dearth of data from Ecuador on the burden of these life threatening diseases entities, where only a very few groups of scientists have reported their experiences, mainly in endemic fungal diseases [3-7].

The aim of this study was to estimate the burden of serious fungal disease in Ecuador by using the available published data on the local incidence or prevalence, or calculate their incidences by applying calculations based on international cohort studies, clinical trials and rates infections already documented in similar groups of patients elsewhere.

\section{Materials and Methods}

A literature search using Google Scholar, Pubmed website, Journals Online and grey literature was done to identify all epidemiology papers reporting fungal infection rates from Ecuador. Given that there is little data on incidence rates Ecuador generated by local studies, the density of fungal infections was calculated by using data generated in other countries using previously described methodology by LIFE [1]. Where no data existed, we used specific populations at risk and fungal infection frequencies in the populations to estimate national incidence or prevalence, depending on the condition. 2012 statistics were derived from the Instituto Nacional de Estadística y Censos (INEC); WHO, PAHO, ONU-AIDS, Index Mundi, Global Asthma Report and GLOBOCAN werereviewed; National data of Ministerio de Salud Pública (MSP), Sociedad de Lucha Contra el Cáncer del Ecuador (SOLCA), Instituto Nacional de Donación y Trasplante de Órganos, Tejidos y Células (INDOT).

The number of HIV/AIDS patients was obtained from epidemiological surveillance of AIDS in Ecuador published in UNAIDS [http://aidsinfo.unaids.org/] and data from MSP. Similar, the proportion of AIDS patients presenting with Pneumocystis pneumonia, Candida esophagitis and with cryptococcal meningitis in 2015 were made by estimates based on literature review of manuscripts addressing incidence rates of such infections for specific set of patients. Pneumocystis pneumonia is usually considered to be associated primarily with HIV and it is inferred that $10.7 \%$ of patients with AIDS develop this type of pneumonia [8].

Nationally representative estimates for the incidence of cryptococcosis are difficult to establish because cryptococcosis is not a reportable disease in Ecuador. According to Ruhnke et al. [9] 5\% of new cases of AIDS each year develop cryptococcal meningitis. In Ecuador according to MSP 3,546 new AIDS cases were recorded in 2014. Another analysis found the prevalence of cryptococcal antigenemia is $2.9 \%$, among HIV patients [10]. 
In most populations, it is assumed that $90 \%$ of patients with late stage HIV who are not being treated with highly active antiretroviral therapy (HAART) will develop oral candidiasis [11-12]. Earlier data from an US cohort study showed that oral candidiasis may occur in $16 \%$ of HIV/AIDS individuals on HAART [13]. Esophageal candidiasis was based on the assumption that $20 \%$ of patients with HIV patients with CD4 counts under $200 \times 10^{6} / \mathrm{L}$ who are not on antiretroviral therapy are affected by this condition, as well as $5 \%$ of those on therapy. Estimation of this annual burden is challenging if a large percentage of patients not on therapy have CD4 cell counts of $>200 \times 10^{6} / \mathrm{L}$ [1415]. There are no data in Ecuador about how many HIV-infected patients with CD4 counts $<200 \times 10^{6} / \mathrm{L}$. We estimated $\sim 10,000$.

Cases of candidemia in hospitalized patients were based on the prevalence documented between November 2008 and October 2010 in three tertiary care hospitals of Ecuador as a part of multicenter study in Latin America [16]. The incidence of candidemia per 1000 admissions was 0.90 (range $0.30-1.10$ ) and the incidence per 1000 patients day was 0.16 $(0.10-0.17)$. The population candidemia rate is estimated at 5/100,000. We assumed $35 \%$ of candidemia episodes occur in ICU, and that the rate of Candida peritonitis is $\sim 50 \%$ of the ICU candidemia rate [17-18].

The number of tuberculosis (TB) cases (from 2011), were taken from the epidemiological surveillance registry in MSP [19]. It is assumed that $22 \%$ of patients with lung cavities, and $2 \%$ of those without cavities, following pulmonary tuberculosis (PTB) will develop chronic pulmonary aspergillosis (CPA) [20]. Patients with PTB are expected to represent $\sim 25 \%$ of the total number of CPA cases annually [21] and so the total prevalence of CPA from any cause is estimated using the national PTB figures [20].

Asthma rates in adults were obtained from multiple sources and $7 \%$ of the adult population was used for estimates [22]. The risk of allergic bronchopulmonary aspergillosis (ABPA) was estimated at $2.5 \%$ based on previous studies [23]. The rate of severe asthma with fungal sensitization (SAFS) was estimated as the worst $10 \%$ of the total asthma population of whom at least 33\% have fungal sensitization [24].

The national cancer database is produced by the National Cancer Registry of SOLCA [25], which reports that in the period of 2001-2005 tumors of the hematopoietic and reticuloendothelial systems are within the 25 most frequent malignancies, occupying the fourth place $(5.5 \%)$ in males, and the sixth place $(4.5 \%)$ in females. According to the relative position of the 25 most frequent malignant tumors in males, lymphoma (6\%) and leukemia (4\%) that are in the fourth and fifth places respectively. Data in females differ slightly, showing $4.3 \%$ in lymphoma (sixth place), 3.6\% leukemia (eighth place). Lymphoid leukemia (56\%) has been reported as the most common in Quito general population and myeloid leukemia is $36 \%$. The latter, is more frequent in adults and represents 58\%. A study among indigenous people in the Amazon region of Ecuador, reported that leukemia was one of the most common types of cancer in that population [26]. Ecuador's data are also reported by the International Agency for Research in Cancer, through the GLOBO-CAN project, showing an estimated incidence (2008) of crude rates for leukemia at 6.1/100,000; acute myeloid leukemia is the most common leukemia in adults [27]. Nine hundred and thirty cases of leukemia were registered in 2014. An estimated 1,035 patients had lung cancer in 2012.

It is assumed that non-AML haematological conditions in total represent the same population incidence of invasive aspergillosis (IA) as AML patients; in each group there 
is an incidence of approximately 10\% [28]. Further, it is assumed that the incidence of IA in allogeneic haematopoietic stem cell transplants is 8\% [28]. IA is also associated with solid organ transplantation, although the reported incidence varies by both dataset and anatomical site. The Transplant-Associated Infection Surveillance Network data suggest an IA 1 year cumulative incidence of $0.5 \%$ of renal, $2.0 \%$ of heart, $0.9 \%$ of liver and $9.1 \%$ of lung transplants [29]. Given the size of this dataset, it provides most precise disease rates and we have adopted these. Ecuadorian transplant data were obtained from the 2013 INDOT report on organ transplant and organ donation registry [30].

Recurrent Candida vaginitis (more than 4 per year) included in the context of serious infections due to its impact in quality of life as well as potential source for colonization by azole-resistant Candida strains [31]. For recurrent Candida vaginitis, the number of cases was based on $6 \%$ expected prevalence on women aged 15 to 50 years old [31]. According to the INEC, the population of age group in Ecuador is 5,126,552 women.

\section{Results and Discussion}

This is the first attempt to summarise epidemiological data on the prevalence of serious fungal disease in Ecuador and use these data for modeling burden. There are no epidemiology papers that have directly reported incidence, prevalence or fungal infection rates, so every estimate is based on a previously published modeling approach that has been applied in many countries by the LIFE program [1].

In 2012, Ecuador had a population of 14,483,495 people [2]. Nowadays Ecuador is considered an upper middle income country with a per capita gross domestic product of 5,402 US dollars in 2014. Demographic data of the Ecuadorian population are presented in Table 1, including the main at risk categories for fungal diseases.

Douce et al. described the first cases of histoplasmosis in AIDS patients in Ecuador in 2002. Most patients had pancytopenia, hepatitis, and diffuse reticulonodular pulmonary infiltrates. The fastest and most reliable diagnostic approach was with bone marrow biopsy. Within 6 months, 83\% with disseminated histoplasmosis died [37]. In this study, histoplasmosis was the most frequent fungal disease after cryptococcosis in AIDS patients. According to the data of the study of Ortega et al, [38] which included 675 people with AIDS, the prevalence of Histoplasma capsulatum was $11.1 \% ; 77 \%$ males and $23 \%$ females. The age range of greatest prevalence was 30 to 39 years in $43 \%$ followed by 20 to 29 year in $23 \%$. The main risk associated with Histoplasma infection was: place of origin, living by the coast (45\%) and occupation such as farmers and poultry workers (33\%). Almost all (92\%) histoplasmosis present with CD4 cell counts $<200$ cell/ $\mu 1$ so this number represents the greatest risk for most opportunistic infections including oral candidiasis. Based on this data the estimated global burden of disseminated histoplasmosis is 1,110 cases in Ecuador and the estimated burden of oral and oesophageal candidiasis is shown in table 2. The estimation for burden of oral and oesophageal candidiasis in the same study was $50 \%$.

Nationally representative estimates for the incidence of cryptococcosis are difficult to establish because cryptococcosis is not a reportable disease in Ecuador Assuming $\sim 10,000 \mathrm{HIV} / \mathrm{AIDS}$ patients have <200 CD4 cell counts, Pneumocystis pneumonia affected at least $1,070(10.7 \%)$ patient and cryptococcal meningoencephalitis $700(7 \%)$. The overall incidence was 0.12 to 0.4 cases per 100,000 [32]. The widespread 
availability of HAART in Ecuador has helped improve the immune systems of $85 \%$ HIV patients in 2012 reducing vulnerability to infection with Cryptococcus. However due to economic and political factors the percentage of HIV patients on HAART patients has reduced to an estimated $70 \%$ in subsequent years. The burden (and our estimates) of oral and oesophageal candidiasis in HIV patients depends partly on HAART therapy delivery.

Of the 5,352 cases of tuberculosis (TB) in 2014, mostly in HIV negative people, 3,649 (79.6\%) had pulmonary tuberculosis [19]. Using the approach taken in Denning et al. the 5-year point prevalence of chronic pulmonary aspergillosis (CPA) following TB, assuming a $22 \%$ cavitation rate following therapy. Assuming that 3,175 (88\%) of them survived to at least 12 months after diagnosis we estimate that annually at least 133 patients develop CPA following pulmonary tuberculosis, and the prevalence over 5 years is 420 patients. It was assumed that TB was the underlying diagnosis of CPA in $20 \%$ of cases [20-21], and so the total CPA prevalence is 2,100 patients.

Estimates of asthma prevalence in adults are around 7\% [33]. Assuming 2.5\% of asthmatics have ABPA, there will be 26,642 Ecuadorian patients with ABPA. The patients with severe asthma with fungal sensitization (SAFS) were 136,404 and then $33 \%$ of this for those who are sensitised $(45,013)$. It is likely that some overlap exists between these groups, depending on the severity of asthma in the ABPA patients and the number of SAFS patient sensitized to fungi other than Aspergillus. ABPA is an important complication of cystic fibrosis, but the average survival of patients with CF in Ecuador is 9.5 years (Table 2).

According to the National Bureau of Statistics and Analysis of Health Information Ministry of Public Health of Ecuador, 31,214 outpatients were seen in consultation with COPD in 2013 [34]. The COPD burden in Ecuador is estimated as 228,355 (Table 1). Recently over $10 \%$ of patients with chronic obstructive airways disease (COPD) were found to be sensitized to A. fumigatus and this was associated with worse pulmonary function [35] so we expect 22,835 patients with COPD and 'allergic' or chronic aspergillosis.

A recent review of oral fungal infections in patients receiving cancer therapy, for all cancer treatments, the weighted prevalence of clinical oral fungal infection was found to be $7.5 \%$ pretreatment, $39.1 \%$ during treatment, and $32.6 \%$ after the end of cancer therapy [9]. These rates may differ each year but may be used as an estimate for current calculations. Each year 6,000 new cancer diseases (including hematological cancers) are recorded. Assuming that the majority of cancer patients $(>90 \%)$ receive anticancer treatment, 450 (pretreatment) - 2100 (35\% during/after cancer treatment) episodes of oral candidiasis can be calculated resulting in a total of 2,550 episodes each year.

The most important risk factor for IA has historically been neutropenia, and we estimate 124 cases of IA in leukaemia patients. According to 2015 INDOT data in Ecuador they were 322 transplants (Table 2). We estimate the incidence of IA in allogeneic hematopoietic stem cell transplant as 3 and 1 case after renal transplantation. Assuming a $20 \%$ hospital admission rate for COPD, and a 1.3\% IA rate among the admitted patients, we anticipate 594 cases of IA complicating COPD. We would expect a small number of IA cases in those with lung cancer, about 27, based on data from China.

The incidence of bloodstream infections in Latin America varies between 1.2 and 5.3 (0.06 to 0.39 cases per 1,000 patient/days) [16]. Preliminary data in three hospitals in 
Ecuador showed an incidence rate of 0.90 cases per 1,000 admissions and 0.16 cases per 1,000 patient-days. $C$. albicans was the most common species $(52.2 \%)$, followed by $C$. parapsilosis (30.4\%) and C. tropicalis (10.9\%) [16].

A $6 \%$ rate was assumed in women to have recurrent vaginal candidiasis (four or more episodes per year), which correlates with 308,000 Ecuadorian women with recurrent vaginal thrush in any 1 year. A study of 213 adolescent girls in a tropical area of Ecuador found vaginal candidosis in 24\% [36]. An internet survey in five European countries and the USA found a rate of $9 \%$ of recurrent VVC, but it is likely that many over-diagnose this and mistake it for bacterial vaginosis and other problems. Therefore we have arbitrarily reduced the rate to $6 \%$.

In Latin America the causes of the increase in asthma are associated with urbanization; in Ecuador $68 \%$ of the population live in urban zones, many having migrated from the rural areas. Rodriguez et al., sought to examine the relationship between asthma prevalence and level of urbanization in 59 small rural communities in transition from northern Ecuador. With a total of 4,183 questionnaires administered to children and adolescents, the percentage coverage in the communities was about $95 \%$ of the study population. The average prevalence of asthma was found to be $10.1 \%$; with a large variation of $0.0 \%$ to $31.4 \%$ [39]. ABPA rates may be higher in rural areas.

As in Peru and Bolivia, Ecuador artisanal mining is focused primarily on finding gold, but some other mineral mining goes on. In Ecuador, some 1,500 children work in mining and 22,950 are at risk from working in mines. Often, children and adolescents work in the mines and quarries after their school classes or during their vacation, but stop when the whole family switches activity, such as agriculture [40]. Therefore the number of cases of asthma and ABPA probably is higher. These occupations probably also contribute to COPD burden.

It is considered that for every one million, there are 5,000 workers with occupational asthma [39]. If the economically active population in Ecuador is 8,278,922, we expect 41,395 workers having occupational asthma [41]. Some of these will be attributable to fungal exposure but it is difficult to estimate how many.

Approximately 8.5 million people who live in Ecuador are in risk areas for endemic fungal infection diseases. Tropical and subtropical areas where transmission exists or may exist, these risk areas are in almost all provinces. In other words, $61 \%$ of Ecuador's population lives in areas with endemic mycoses such as histoplasmosis, paracoccidoidomycosis, sporotrichosis, and chromoblastomycosis. None are reportable diseases in Ecuador and we are unable to estimate the incidence of prevalence, in people not infected with HIV.

Although fungal infections occupy an important place in infectious processes with a high burden of morbidity and mortality there are many limitations for acute diagnosis of fungal diseases in Ecuador. Limitations in reagents for the diagnosis of these diseases are frequent. Conventional diagnostic tests: such as direct microscopy, histopathology and culture are routinely used, but not galactomannan, $\beta$-D-glucan, or DNA detection tests and may have impacted on the ability to diagnose invasive fungal infections. There is a limitation of resources and expertise in the laboratories and many do not have enough trained specialist technicians on fungi. Moreover scientific skill development 
and medical education on fungal diseases is necessary. Liposomal amphotericin B, flucytosine and topical natamycin are not available in Ecuador.

\section{Conclusion}

Our estimates indicate that over $3 \%$ of the Ecuadorian population is estimated to suffer from a serious fungal infection each year $(433,856)$. If recurrent vaginal thrush is excluded, 125,263 populations are estimated to be affected. Using local data available national and international literature estimates of the incidence or prevalence of fungal infections, almost half a million people are affected. This study is the first to estimate de burden of serious fungal diseases in Ecuador. We consider it is necessary to include these infections as reportable diseases. 
Table 1 Demographic data for the calculation of fungal-related diseases in Ecuador

\section{Population}

Population data (year 2012 INEC) 14,483,495

Population living outside urban zones 5,392,713

Urban population: $67.5 \%$ of total population (2011)

Rate of urbanization: $2.13 \%$ annual rate of change (2010-15 est.)

Female sex 7,305,812

In childbearing age (15-45 years) $1,065,658$

Male sex 7,177,683

Women and men over 40 years 4.262 .630 (29\%)

Children 4,528,425 (28, 5\%)

HIV and AIDS estimates (2015) [42]

New AIDS cases

HIV + on antiretroviral therapy (HAART)

Patients at risk (CD4 count $<200$ and which developed AIDS) No data

Leukaemia, Transplant and other immunocompromised patients 2014 year Leukaemia 939 (4\% of all cancers excluded NMSC)

All cancers excluded NMSC 23,360

Allogeneic haematopoietic stem cell transplantation (2015)

Solid organ transplant 2015 year:

Renal transplant procedures

Lung transplant procedures

Heart transplant procedures

0

Liver transplant procedures

14

Corneal transplant procedures

\section{Pulmonary diseases}

Tuberculosis $\quad 5,352$

Pulmonary tuberculosis $\quad 3,649$

Annual incidence $\quad 38.2 / 100,000$

HIV-positive TB patients $\quad 637$ (13\%)

Lung cancer $\quad 1,035$

\section{Chronic obstructive pulmonary disease}

Prevalence (for patients over 40 years) $\quad 228,355$

Chronic obstructive pulmonary disease admissions to hospital per year $\quad 4,023$

Consultations and outpatient care

\section{Asthma}

In adults $>40$ years

In adults (18-45 years)

All adults 
Critical care and surgery cases (2012 year)

Critical care beds nationally

$781(3 \%)$

Overall hospital admissions

$1,153,237$

Peritoneal dialysis patients

9,635

NMSC $=$ non-melanoma skin cancer,

HAART $=$ Highly active antiretroviral therapy

INEC $=$ National Institute of Statistics and Census

HIV = Human Immunodeficiency Virus

AIDS $=$ acquired immunodeficiency syndrome

$\mathrm{TB}=$ Tuberculosis

CD4 = Cluster difference 4 
Table 2. Serious Fungal burden infections in Ecuador

\begin{tabular}{|c|c|c|c|c|}
\hline Type of disease & $\begin{array}{l}\text { Serious } \\
\text { invasive fungal } \\
\text { infections }\end{array}$ & $\begin{array}{l}\text { Predominant } \\
\text { groups at risk }\end{array}$ & $\begin{array}{l}\text { Risk } \\
\text { populatio } \\
\text { n size }\end{array}$ & $\begin{array}{l}\text { Affected } \\
\text { patients }\end{array}$ \\
\hline \multirow[t]{7}{*}{$\begin{array}{l}\text { HIV/AIDS } \\
37,000\end{array}$} & Pneumocytosis & $\begin{array}{l}\text { HIV/AIDS <200 } \\
\text { CD4 }\end{array}$ & 5,000 & 535 \\
\hline & Histoplasmosis & $\begin{array}{l}\text { HIV/AIDS } \\
<200 \mathrm{CD} 4 \\
\end{array}$ & 5,000 & 550 \\
\hline & Cryptococcosis & $\begin{array}{l}\text { HIV/AIDS } \\
<200 C D 4\end{array}$ & 5,000 & 350 \\
\hline & Oral candidiasis & Those on HAART & 25,900 & 4,144 \\
\hline & Oral candidiasis & Not on HAART & 11,100 & 9,990 \\
\hline & $\begin{array}{l}\text { Oesophageal } \\
\text { candidiasis }\end{array}$ & Those on HAART & 25,900 & 1,295 \\
\hline & $\begin{array}{l}\text { Oesophageal } \\
\text { candidiasis }\end{array}$ & Not on HAART & 11,100 & 2,220 \\
\hline \multirow[t]{6}{*}{ Transplantations } & $\begin{array}{l}\text { Aspergillus } \\
\text { infections }\end{array}$ & $\begin{array}{l}\text { Hematopoietic } \\
\text { stem cell } \\
\text { transplantation }\end{array}$ & 33 & 3 \\
\hline & & Renal & 118 & 1 \\
\hline & & Hepatic & 14 & 1 \\
\hline & & Lung & 0 & 0 \\
\hline & & Heart & 0 & 0 \\
\hline & & $\begin{array}{l}\text { All transplantation } \\
\text { without corneal } \\
\text { transplant }\end{array}$ & 165 & 5 \\
\hline Leukemia & Aspergillosis & $\begin{array}{l}\text { Leukemia } \\
(6.1 / 100000 \mathrm{hab})\end{array}$ & 930 & 124 \\
\hline Tuberculosis & CPA & Pulmonary TB & 3,649 & 420 \\
\hline $\begin{array}{l}\text { Chronic } \\
\text { respiratory } \\
\text { disease }\end{array}$ & $\mathrm{CPA}$ & $\begin{array}{l}\text { COPD, asthma, } \\
\text { pneumothorax, } \\
\text { lung surgery, } \\
\text { sarcoidosis etc }\end{array}$ & $>530,000$ & 1,680 \\
\hline COPD & $\begin{array}{l}\text { Invasive } \\
\text { Aspergillosis }\end{array}$ & Total of COPD & 228,355 & 594 \\
\hline Cystic Fibrosis & ABPA & $\begin{array}{l}\text { Cystic Fibrosis } \\
\text { Patients }\end{array}$ & 178 & 13 \\
\hline \multirow[t]{2}{*}{ Asthma } & ABPA & Asthma $\geq 40$ years & 298,384 & 26,642 \\
\hline & & SAFS & 136,404 & 45,013 \\
\hline \multirow[t]{2}{*}{ Candidiasis } & Oral candidiasis & Cancer diseases & 23,400 & 9,945 \\
\hline & Candidemia & $\begin{array}{l}\text { Incidence per } 1,000 \\
\text { admissions } 0,90\end{array}$ & $1,153,237$ & 1,037 \\
\hline Not serious & & Recurrent candida & $5,126,552$ & 307,593 \\
\hline
\end{tabular}




\begin{tabular}{|l|l|l|l|l|}
\hline $\begin{array}{l}\text { invasive fungal } \\
\text { infection }\end{array}$ & $\begin{array}{l}\text { vaginitis (women } \\
>15-50 \text { years old) }\end{array}$ & & \\
\hline Total burden & & & & 433,856 \\
\hline
\end{tabular}

Compliance with ethical standards

Conflict of interest

JZ, DWD, APyM, MBO, JMA, nothing to declare 


\section{References}

1 Leading International Fungal Education. http://www.life-worldwide.org/fungaldiseases. Accessed on 12 December 2015

2 Index Mundi (2014) Ecuador demographycs profile 2014 http://www.indexmundi.com/ecuador/demographics_profile.html. Accessed 5 November 2015.

3 Ollague Sierra JE, Ollague Torres JM (2013) New clinical and histological patterns of acute disseminated histoplasmosis in human immunodeficiency virus-positive patients with acquired immunodeficiency syndrome. Am J Dermatopathol 35(2):205-212

4 Ramos-E-Silva M, Saraiva Ldo E (2008) Paracoccidioidomycosis. Dermatol Clin 26(2):257-69

5 Gil-Brusola A1, Pemán J, Santos M, Salavert M, Lacruz J, Gobernado M (2007) Disseminated histoplasmosis with hemophagocytic syndrome in a patient with AIDS: description of one case and review of the Spanish literature. Rev Iberoam Micol 24(4):312-316

6 Müller-Stöver I, Tintelnot K, Richter J, Häussinger D (2014) A 55-year-old woman with cough, fever, swelling of joints, and exanthema after a trip to Ecuador. Internist (Berl) 55(8):976-980

7 Wolff M (1999) Outbreak of acute histoplasmosis in Chilean travelers to the ecuadorian jungle: an example of geographic medicine. Rev Med Chil 127(11):13591364

8. Coyle PV, McCaughey C, Nager A, McKenna J, O’Neill H, Feeney SA, Fairley D, Watt A, Cox C, Curran T (2012) Rising incidence of Pneumocystis jirovecii pneumonia suggests iatrogenic exposure of immune-compromised patients may be becoming a significant problem. J Med Microbiol 61:1009-1015

9. Ruhnke M, Groll AH, Mayser P, Ullmann AJ, Mendling W, Hof H, Denning DW7; University of Manchester in association with the LIFE program (2015) Estimated burden of fungal infections in Germany Mycoses. 58 Suppl 5:22-28.

10. McKenney J, Smith RM, Chiller TM, Detels R, French A, Margolick J, Doherty B, Klausner JD (2014) Prevalence and correlates of cryptococcal antigen positivity among AIDS patients - United States, 1986-2012. Clin Infect Dis 60(6):959-965 
11. Gazzard BG, Smith D (1990) Oral candidosis in HIV-infected patients. Br J Clin Pract Suppl 71:103-108

12. Matee MI, Scheutz F, Moshy J (2000) Occurrence of oral lesions in relation to clinical and immunological status among HIVinfected adult Tanzanians. Oral Dis 6:106-111

13. Patton LL, McKaig R, Strauss R, Rogers D, Eron JJ, Jr (2000) Changing prevalence of oral manifestations of human immuno-deficiency virus in the era of protease inhibitor therapy. Oral Surg Oral Med Oral Pathol Oral Radiol Endod 89:299-304

14. Smith E, Orholm, M (1990) Trends and patterns of opportunistic diseases in Danish AIDS patients 1980-1990. Scand J Infect Dis 22:665-672

15. Buchacz K, Baker RK, Palella FJ, Jr Chmiel JS, Lichtenstein KA, Novak RM, Wood KC, Brooks JT, HOPS Investigators (2010) AIDS - defining opportunistic illnesses in US patients, 1994-2007: a cohort study. AIDS 24:1549-1559

16. Nucci M, Queiroz-Telles F, Alvarado-Matute T, Tiraboschi IN, Cortes J, Zurita J, Guzman-Blanco M, Santolaya ME, Thompson L, Sifuentes-Osornio J, Echevarria JI, Colombo AL; Latin American Invasive Mycosis Network (2013) Epidemiology of candidemia in Latin America: a laboratory-based survey. PLoS One 8(3):e59373

17. Pfaller MA, Diekema DJ (2007) Epidemiology of invasive candidiasis: a persistent public health problem. Clin Microbiol Rev 20(1):133-163

18. Eggimann P, Que YA, Revelly JP, Pagani JL (2014) Preventing invasive candida infections. Where could we do better? J Hosp Infect. 89(4):302-308.

19. http://www.salud.gob.ec/wp-content/uploads/2014/05/OPS-libro-prevenciontuberculosis.pdf

20. Denning DW, Pleuvry A, Cole DC (2011) Global burden of chronic pulmonary aspergillosis as a sequel to pulmonary tuberculosis. Bull World Health Organ 89:864872

21. Smith NL, Denning DW (2011) Underlying conditions in chronic pulmonary aspergillosis including simple aspergilloma. Eur Respir J 37:865-872 
22. Global Asthma Network, International Union Against Tuberculosis and Lung $\begin{array}{llllll}\text { Diseases (2014) } & \text { The global asthma } & \text { report } & \end{array}$ http://www.globalasthmareport.org/burden/burden.php. Accessed 26 October 2015

23. Denning DW, Pleuvry A, Cole DC (2013) Global burden of allergic bronchopulmonary aspergillosis with asthma and its complication chronic pulmonary aspergillosis in adults. Med Mycol 51:361-370

24. Denning DW, Pashley C, Hartl D, Hartl D, Wardlaw A, Godet C, Del Giacco S, Delhaes L, Sergejeva S (2014) Fungal allergy in asthma-state of the art and research needs. Clin Transl Allergy 4:14

25. Cueva P, Yérez J (2009) National Cancer Registry: Cancer Epidemiology in Quito 2003-2005, 15rd. Sociedad de Lucha contra el Cáncer, Quito

26. San Sebastián M, Hurtig AK (2004) Cancer among Indigenous People in the Amazon Basin of Ecuador, 1985-2000. Panamericana de Salud Pública 5(16):328333

27. Ferlay J, Soerjomataram I, Ervik M, Dikshit R, Eser S, Mathers C, Rebelo M, Parkin DM, Forman D, Bray, F. (2012) GLOBOCAN 2012 v1.0, Cancer Incidence and Mortality Worldwide: IARC CancerBase. Lyon, France: International Agency for Research on Cancer; 2013. http://globocan.iarc.fr. Accessed 24 June 2016.

28. Lortholary O, Gangneux, JP, Sitbon, K, Lebeau, B, de Monbrison F, Le Strat Y, Coignard B, Dromer F, Bretagne S, French Mycosis Study Group (2011) Epidemiological trends in invasive aspergillosis in France: the SAIF network (20052007). Clin Microbiol Infect 17:1882-1889.

29. Pappas PG, Alexander BD, Andes DR, Hadley S, Kauffman CA, Freifeld A, Anaissie EJ, Brumble LM, Herwaldt L, Ito J, Kontoyiannis DP, Lyon GM, Marr KA, Morrison VA, Park BJ, Patterson TF, Perl TM, Oster RA, Schuster MG, Walker R, Walsh TJ, Wannemuehler KA, Chiller TM. (2010). Invasive fungal infections among organ transplant recipients: results of the Transplant-Associated Infection Surveillance Network (TRANSNET). Clin Infect Dis 50:1101-1111

30. Ministerio de Salud Pública del Ecuador (2016) Instituto Nacional de Donación y Trasplante de Órganos, Tejidos y Células. http://www.donaciontrasplante.gob.ec/indot. Accessed 15 April 2016 
31. Foxman B, Muraglia R, Dietz JP, Sobel JB, Wagner J (2013) Prevalence of recurrent vulvovaginal candidiasis in 5 European Countries and the United States: results from an Internet Panel Survey. J Low Genit Tract Dis 17: 340-34532. Mirza SA, Phelan M, Rimland D, Graviss E, Hamill R, Brandt ME, Gardner T, Sattah M, de Leon GP, Baughman W, Hajjeh RA (2003) The changing epidemiology of cryptococcosis: an update from population-based active surveillance in large metropolitan areas, 1992-2000. Clin Infect Dis 15:789-794

33. To T, Stanojevic S, Moores, Gershon AS, Bateman ED, Cruz AA, Boulet LP (2102) Global asthma prevalence in adults: findings from the cross-sectional world health survey BMC Public Health. 12:204.

34. Data of COPD. www.ecuadorencifras.gob.ec/camas-y-egresos-hospitalarios/

Accessed June 2014

35. Denning DW, O'Driscoll BR, Hogaboam CM, Bowyer P, Niven RM. (2006) The link between fungi and severe asthma: a summary of the evidence. Eur Respir $\mathbf{J}$ 27(3):615-626.

36. Vaca M1, Guadalupe I, Erazo S, Tinizaray K, Chico ME, Cooper PJ, Hay P (2010) High prevalence of bacterial vaginosis in adolescent girls in a tropical area of Ecuador. BJOG. 117(2):225-228.

37. Douce R, Maldonado D, Vásconez O, Zurita J. (2002) Histoplasmosis opportunistic infection common in Ecuador. Vozandes 4(1) 48-51

38. Ortega D, Zambrano J. Thesis for obtaining medical degree. Frequency Histoplasma capsulatum infection and associated risk factors in people living with the HIV / AIDS comprehensive care units of general hospital Dr. Enrique Garcés Hospital and Dr. Eugenio Espejo specialty from 2003 to 2012. PUCE 2012

39. Rodriguez A, Vaca M, Oviedo G, S Erazo S, Chico M, Teles M, Barreto ML, Rodrigues LC, Cooper PJ (2011) Urbanization is associated with prevalence of childhood asthma in diverse, small rural communities in Ecuador

Thorax doi:10.1136/thoraxjnl-2011-200225

40. C\&T Science and work. Occupational asthma an invisible and growing social problem. http://www.saudeetrabalho.com.br/download/asma-mantilla.pdf. Accessed February 2015 
41. http://instituciones.msp.gob.ec/somossalud/index.php/enterate/246-235-millones-depersonas-en-el-mundo-padecen-asma. Accessed January 2015

42. UNADIS (2015) HIV and AIDS estimates 2015.

http://www.unaids.org/en/regionscountries/countries/ecuador. Accessed 25 June 2016 